\title{
sciendo

\section{Latvian Electric Vehicle Fast Charging Infrastructure: Results of the First Year of Operation}

\author{
Aivars RUBENIS ${ }^{1,2 *}$, Aigars LAIZANS ${ }^{2}$, Andra ZVIRBULE ${ }^{2}$ \\ ${ }^{1}$ Ivory Group, Skolas iela 15-7, Ikskile, LV-5001, Latvia \\ ${ }^{2}$ Latvia University of Life Sciences and Technologies, Liela 1, Jelgava, LV-3001, Latvia
}

\begin{abstract}
This article presents preliminary analysis of the Latvian national EV fast - charging network after the first year of operation. The first phase of Latvian national EV fast-charging network was launched in 2018 with 70 charging stations on the TEN-T roads and in the largest towns and cities. The article looks at the initial results, both looking at the total capacity utilization for individual charging stations, determining the hourly charging distribution; and to the utilization of the network as a whole. The results present that there is a very large dispersion of the data, most of the charging events happening in a few charging stations in and around the capital of Latvia. However, there have been charging events in all charging stations, even in the most remote ones. Even more skewed distribution was observed analyzing the charging habits of the EV users, with $10 \%$ of users accounting for more than half of the charging events. This should be taken into account when considering applying the results for the future, expecting larger number of electric vehicles in Latvia.
\end{abstract}

Keywords - Electric vehicles; EV charging infrastructure, EV charging statistics

\begin{tabular}{|llll}
\hline Nomenclature & & \\
AC & Alternating Current & EV & Electric Vehicle \\
CCS & Combined Charging System & GHG & Greenhouse Gasses \\
CSDD & Latvian Road Traffic Security Directorate & PEV & Plug-in Electric Vehicle \\
DC & Direct Current & SoC & State of Charge \\
EU & European Union & TEN-T & Trans-European transport network \\
\hline
\end{tabular}

\section{INTRODUCTION}

Latvian national electric mobility development plan for the years 2014-2016 was created [1] as a first step to decrease $\mathrm{CO}_{2}$ production in transport sector in Latvia, as then declared in climate and energy package [2], which was agreed by Council and Parliament at the end of 2008 and stipulated in European Commission White Paper "Roadmap to a Single European Transport Area - Towards a competitive and resource efficient transport system" [3]. The roadmap was later implemented in Directive 2014/94/EU on the deployment of alternative fuels infrastructure [4] and laid out in EU-wide targets and policy objectives for the period from 2021 to 2030 in the 2030 climate and energy framework [5]. The targets for renewables and energy efficiency were revised upwards in 2018 to reflect the commitments under Paris agreement [6] now aiming at at least $40 \%$ cuts in greenhouse gas emissions (from 1990 levels).

\footnotetext{
* Corresponding author.

E-mail address: aivars.rubenis@ivorygroup.eu
} 
Since then the decrease of $\mathrm{CO}_{2}$ emissions has been as important as ever, as stressed in IPCC special report on the impacts of global warming of $1.5^{\circ} \mathrm{C}$ above pre-industrial level [7]. Progress in decrease of $\mathrm{CO}_{2}$ emissions from transport sector has been lagging behind other sectors transport is the only major sector in the EU where greenhouse gas (GHG) emissions are still rising - between 1990 and 2016, GHG from transport increased by $18 \%$ in the EU [8].

Under 2030 energy framework, member states are obliged to adopt integrated National Climate and Energy Plans for the period 2021-2030. National Energy and Climate Plan of Latvia 2021-2030 submitted to the European Commission for evaluation, plans to increase the share of renewable energy in the final energy consumption in 2030 to $14 \%$ from current $2.8 \%$ [9], which is an ambitious target. Much of the work in Latvia was focused on energy efficiency especially in building sector [10], with transportation lagging behind. One of the major work packages in the Latvian electric mobility development plan was setting out an electric vehicle (EV) fast charging network on TEN-T roads. After several delays and changes in the original plan, the first phase of the national fast charging network has been finally deployed in 2018.

The aim of the article is to present initial results and preliminary analysis of the national EV charging network after the first year of operation with intention that it could serve as a first milestone and a reference point for further analysis of EV policy implementation and greenhouse gas emission reduction in Latvia.

There has been research done on results of implementation of charging infrastructure in European Union and other countries. Most of the research has been focusing on charging station location planning and there is not much factual information available on actual charging station use. Furthermore, as there are very few national charging networks, most of the research has been done on particular operator or a city [11] or a specific demonstration project [12]. An example of a nationwide charging network operation in Ireland is presented in [13].

The actual charging network performance analysis in Baltic countries so far has not been extensive. Lithuanian governmental policies regarding EV and early charging infrastructure has been described in [14] and a comprehensive review of rollout of CHAdeMO based charging infrastructure and its initial results in Estonia have been presented in [15]. There have been two studies in Latvia concerning EV charging infrastructure: [16] and [17], however they mostly address the charging station distribution issues and do not illustrate actual charging station usage data.

This research will provide statistics from charging sessions for the first time in Baltic countries thus allowing comparison between countries and providing data for further research.

\section{MethodS}

\subsection{Background Information}

Latvian national electric mobility development plan for the years 2014-2016 was developed during 2013 based on the best practice information available at the time. It was determined that the coverage of the national level EV charging network needs to be deployed to ensure the use of EVs throughout Latvia, as almost no electric vehicles at that time had a driving range exceeding $200 \mathrm{~km}$.

The distribution of network of 235 fast charging stations with a power at least $50 \mathrm{~kW}$ was developed according to the following criteria: the distance between the charging stations should be not more than $30 \mathrm{~km}$ and fast chargers should be installed in populated areas with a ratio of 1 charger per 10000 inhabitants. Latvian Road Traffic Security Directorate (CSDD) was appointed to be responsible for this task. 
In 2017 a report was commissioned by CSDD to analyse whether developments in electric mobility during the previous three years would warrant changes in the national charging network [18]. The report advised decreasing the number of fast charging stations from 235 down to 150 and recommended to prepare for upgrade to the new generation of $150 \mathrm{~kW}$ chargers in the national charging grid - the recommendation that was ignored.

The government accepted proposals for deployment of charging network deployment in two phases:

- Phase 1: on TEN-T roads: keeping the distance between stations $30 \pm 10 \mathrm{~km}$. It was recommended that charging stations are installed in populated areas, even if they are not in the immediate vicinity of the road;

- Phase 2: on the regional roads connecting to TEN-T roads, with the distance between stations $50 \pm 10 \mathrm{~km}$.

In urban and populated areas with population between 5000 and 10000 inhabitants it was suggested keeping 1 charging station; with population between 10000 and 60000 inhabitants - 1 charging station per 10000 people; between 60000 and 100000 - decreasing to 1 charging station per 15000 inhabitants; and for cities over 100000 - decreasing to 1 charging station per 25000 inhabitants.

After several failed procurements, the first 70 charging stations in Phase 1 were gradually installed starting from mid-2018 and the management system was set up starting from the $1^{\text {st }}$ of July 2018.

\subsection{Exclusions}

This research does not include the data from several privately hold and operated charging stations. During Latvia's short-lived support program for EV purchases and charging station installation in 2014 and 174 EVs were purchased and few charging stations were installed, within a couple of months, while the money lasted [19], most of whom have stopped operating by now. Data from these privately held charging stations is not available and has not been included in the analysis.

\subsection{Charging Network Utilization: Energy Use}

Before opening the whole network in 2018, first two fast charging stations were installed in Riga in test mode - first one in Bauskas street in May 2015 and second one in June 2016 Eizensteina Street. These stations were Efacec QC45 chargers with both $50 \mathrm{~kW}$ CHAdeMo [20] and CCS [21] DC charging and $43 \mathrm{~kW}$ Type 2 AC charging.

Until the opening of the EV charging network management system, the data from energy utility company was available, which could be used to analyse energy flows and determine the charging station use indirectly.

The data was available in a semicolon delimited csv format, showing date, time, amount of energy, and energy tariff, as shown in Fig. 1.

$$
\begin{aligned}
& \text { "01.01.2018"; "00:01";"0,824"; "T4 N";"'" } \\
& \text { "01.01.2018";"00:02";"0,828";"T4 N";"'" } \\
& \text { "01.01.2018";"00:03";"0,832";"T4 N";"'" }
\end{aligned}
$$

Fig. 1. Example of available energy consumption data. 
The data was available with a minute interval that allowed precise data analysis. The data was analysed with MS Excel Data analysis toolkit on hourly basis individually for each station to see if there were differences between both charging stations.

\title{
2.4. Charging Behaviour
}

Before opening the whole network in 2018 the electric vehicle charging was for free. Starting from 1st of July, the charging fee was determined by the Cabinet of Ministers of Republic of Latvia, setting the charging price to 15-euro cents per minute [22]. Starting from 1 st of July the detailed data from network management system was available for 73 charging stations connected to the network.

The analysis of charging station usage in Latvia by charger types, charging session power and user analysis was done using data from charging sessions. Although officially the charging network was opened in July, the charging data was available from May 2018 and for this report the data up to November 2018 was used to cover 6 months of operation. As displayed in Fig. 2, the data was available in csv format with individual data for each charging session, however without detailed energy flow information.

\author{
“Charging station, City, ID, Start date, Start time, Total charge amount, Total duration, Connector identifier, \\ Connector label \\ VALMIERA,Valmiera,,01/11/2018,14:37,,,3,Type $243 \mathrm{~kW}, 01 / 11 / 2018$

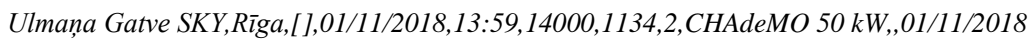 \\ VALMIERA,Valmiera,[],01/11/2018,13:40,19300,1526,1,CCS 50kW,,01/11/2018”
}

Fig. 2. Example of available charging session data.

\section{RESUlTS AND DISCUSSION}

\subsection{Charging Network Utilization}

During first six months of network operation there were in total 12260 charging events and 24.8 MWh of electricity were charged, making $20.2 \mathrm{kWh}$ during an average charging session.

As displayed in Fig. 3(a), there were no charging stations that would not had been used at all since deployment, although there were five stations which were used on average just once a month. Twenty-three charging stations, representing $32 \%$ of all stations, were used at least once a day. Most often 10-30 kWh were charged per session (Fig. 3(b)), $20 \mathrm{kWh}$ being the most frequent, accounting for $39 \%$ of all charging events. The top $1 \%$ of all charging events with charged energy more than $30 \mathrm{kWh}$ per session could be accounted by Tesla cars, who have larger battery capacity. 


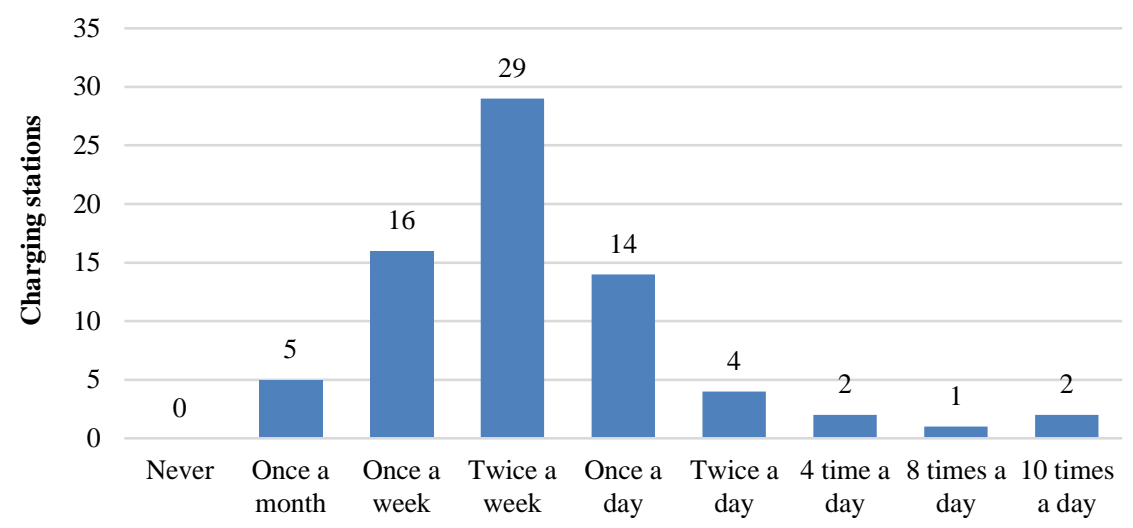

Charging station use

(a)

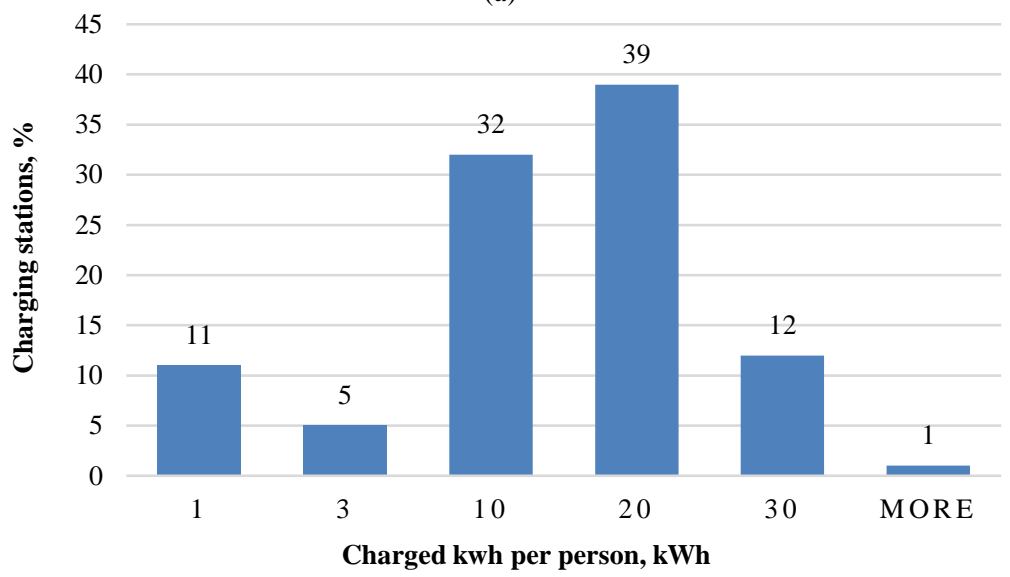

(b)

Fig. 1. (a) National fast charging network utilization in Latvia during first six months of operation in 2018; (b) charged amounts in charging sessions during first six months of operation in 2018.

This was quite different from the results reported in Ireland [13], where the largest segment of the charging of the vehicles was $4-6 \mathrm{kWh}$, representing $19 \%$ of all events. The fast charging in Ireland also demonstrated $8.32 \mathrm{kWh}$ per average charging session. The average charging session data in Amsterdam was very similar - 8.31 kWh [11], which might be explained by higher PHEV proportion in the electric transport fleet and thus higher AC charging proportion.

As it was expected, most of the charging in Latvia was done in the capital city Riga, as most of the EV's are concentrated here $-63 \%$ of all charging were done in 4 charging stations in Riga - furthermore, $52 \%$ were done just in two charging stations: Bauskas and Eizensteina street chargers, which were only two stations used at least 10 times a day on average. This could be explained, that these charging stations were deployed much earlier, and people have known about these stations the longest. Therefore, those two charging stations were used for daily use analysis.

Analysing the charging patterns during the day, it must be noted that there are not individually noticeable patterns on day to day basis - the individual charging events are 
random - the ANOVA analysis for the whole population showed $F=111.36$ and $F$ critical 1.55 and $p=0$, which shows no correlation between data.

The graph visualizing the randomness of charging energy levels for Bauska and Eizensteina street charger utilization in the time periods from 01.06.2016 to 08.02.2017 and from 23.03.2018 to 30.11.2018 is shown in the Fig. 4. It also demonstrates the increase in the charging station use during these periods.
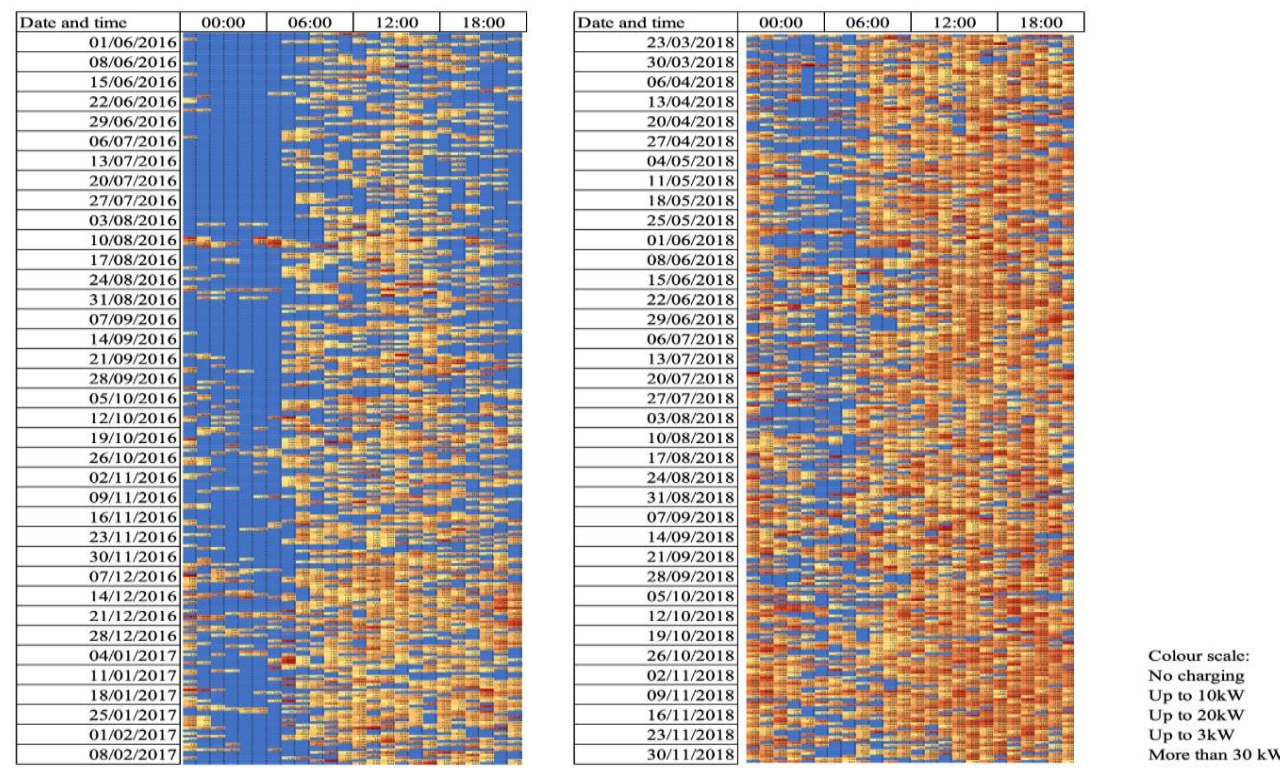

Fig. 2. Visualization of a portion of actual charging station utilization in Bauska and Eizensteina street charging station.

Out of all charging sessions $97 \%$ of charging were DC charging: $60 \%$ were CHAdeMO and $37 \%$ CCS. Only $3 \%$ were AC charging events.

Analysing the charging power levels, $82 \%$ of all charging events were $30 \mathrm{~kW}$ or more (Fig. 5(a)), however, there were significant differences between charging types (Fig. 5(b)). While it was expected that less than $2 \%$ of Type 2 charging events were above the $30 \mathrm{~kW}$ level (there are only few Renault EVs registered in Latvia which can use fast AC charging), there was however noteworthy differences between power levels between CHAdeMO and CCS charging sessions. While $71 \%$ of all CCS sessions were on or above $43 \mathrm{~kW}$, only $55 \%$ of CHAdeMO sessions were on that level. These numbers were closer at $30 \mathrm{~kW}$ level, being respectively $87 \%$ and $83 \%$, and then becoming almost equal at lower charging power levels.

There is insufficient data to explain this difference, however one of the possible explanations could be that because of the low number of EV users (just $700 \mathrm{EV}$ charging cards issued) the specific differences in charge acceptances between few most frequent EV models (VW Leaf for CHAdeMO and VW-eUP for CSS) might affect the data for whole group. 


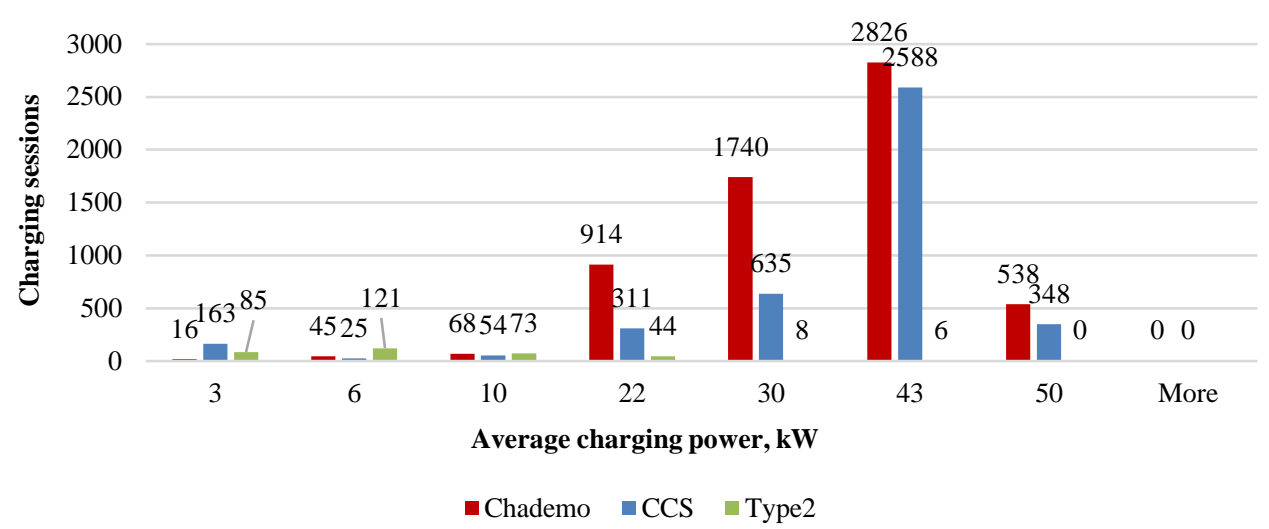

(a)

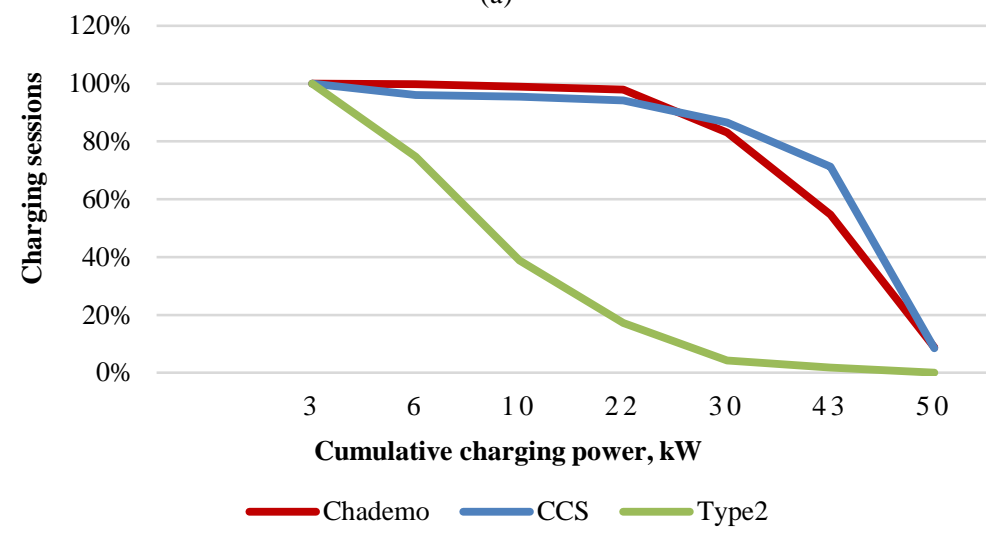

(b)

Fig. 3. (a) Charging power sessions depending on the type of connector, 2018; (b) charging power cumulative distribution depending on the type of connector.

\subsection{User Charging Characteristics}

During the consumer survey in Latvia in 2016, $60 \%$ of the respondents named EV price as the main obstacle for EV purchase, immediately followed by lack of charging network [18]. The same survey also asked the respondents how often they use (or would like to use) fast chargers. The results of survey are presented in Fig. 6(a). 


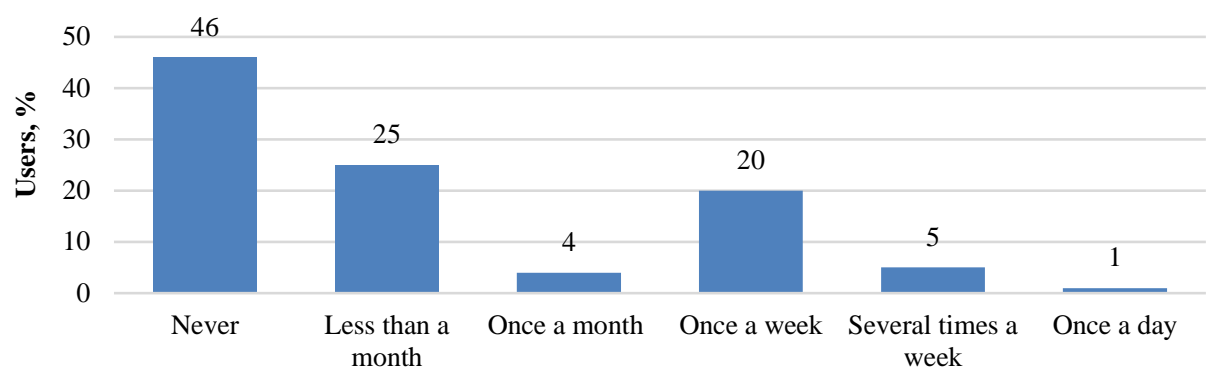

Expected frequency of charging, \%

(a)

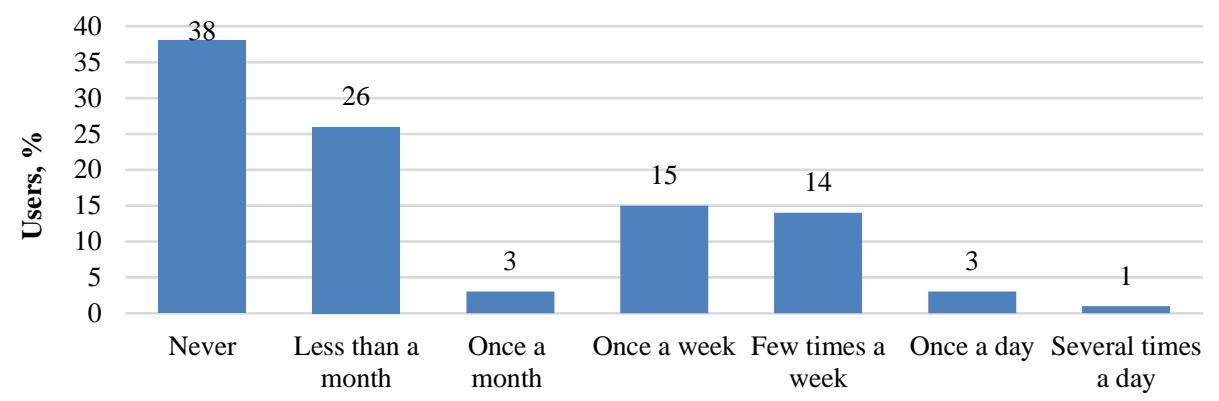

Actual frequency of charging, \%

(b)

Fig. 4. (a) Survey of the EV users about their expected use of fast charging network (2016); (b) actual use of fast charging network within first 6 months of operation in 2018.

The results from the first six months of charging network operations presented in Fig. 6(b) showed that actual frequency of charging was close to the expected: $38 \%$ of the users who had registered for the network card had never used the charging stations during 6 months of operation, while $4 \%$ used it every day, or several times a day and $30 \%$ use it at least once a week.

It must be noted, that the $10 \%$ of users account for the $58 \%$ of all charging events, which makes the charging analysis results vulnerable to the possible disproportionate influence of charging habits of small fraction of users. This makes the data possibly unreliable for further extrapolation for the whole population in the future to simulate larger numbers of electric vehicles in Latvia, as the data might not be representable and could be disproportionately depicting charging habits of just a small part of the potential EV users. Unfortunately, the available data does not allow filtering off the few most frequent users, therefore more detailed analysis will be necessary in the future as more data becomes available.

Analysing the means of payment, most of the payments are done using subscription cards and invoices, only $12 \%$ of charges are paid by credit cards or by means of mobile application and PayPal, which might be visitors from abroad.

\subsection{Charging Sessions}

Charging session analysis was done for two most used chargers in Riga - in Bauskas and Eizensteina streets. 


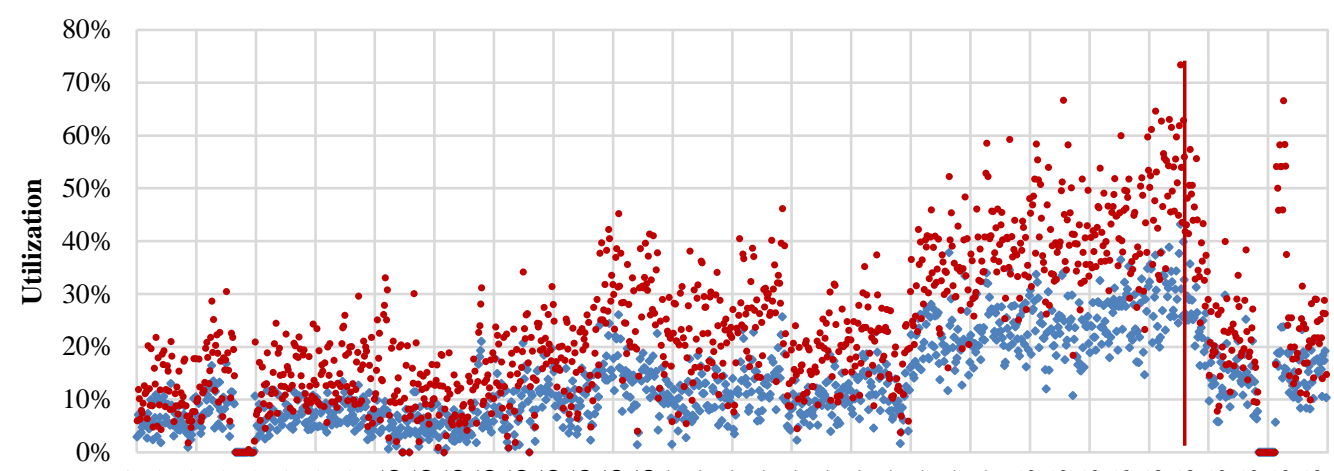

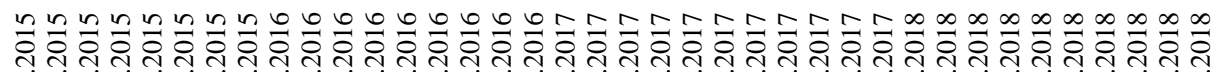

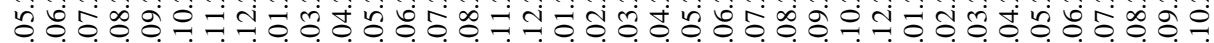
o

\section{Charging station utilization}

- Utilizaton (power) • Utilizaton (time)

(a)

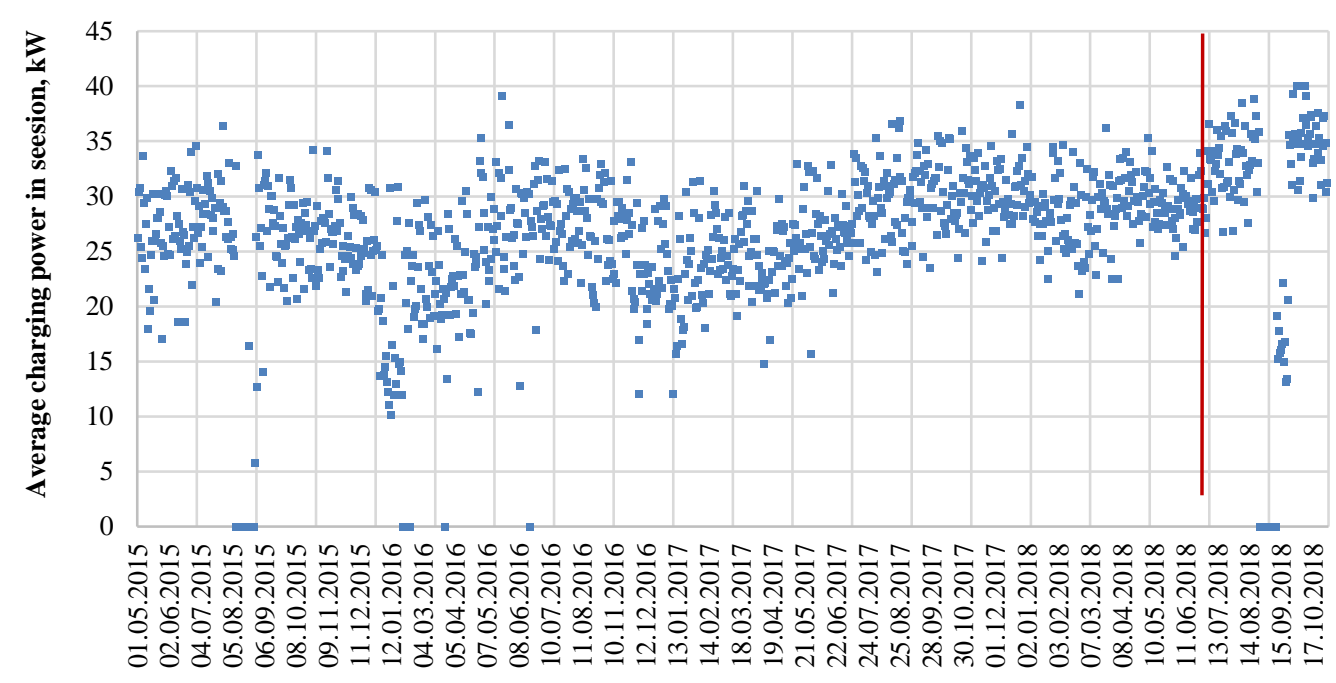

\section{Average charging power}

(b)

Fig. 5. Charging station use in Riga 2015-2018: (a) power and time utilization; (b) average charging power.

As seen in Fig. 7, the charging station utilization was growing steadily from 2015 up to June 2018. Then there was a sharp drop in charging station use when the payments for charging were introduced in July 2018. However, after that there is also a gradual increase in charger use. 
The utilization is higher from time point of view, reaching close to $60 \%$ in Eizensteina street and $70 \%$ in Bauskas street, while from the energy capacity point of view the charging stations were used up to $35 \%$ at the best of times.

It can be noted that starting from the moment of introduction of payments for charging, the average charging power level has gone up, which suggests that people choose to fast-charge their vehicles only when the batter is depleted more and avoid slower AC charging.

Analysing the charging patterns during the day the ANOVA analysis for the whole population showed no correlation between data. However, when creating average hourly power charge levels based on the day of the week, the averages were closely distributed. As shown in the Fig. 8, there is distinct hourly charging pattern for both charging stations, which seems not to depend on the day of the week.

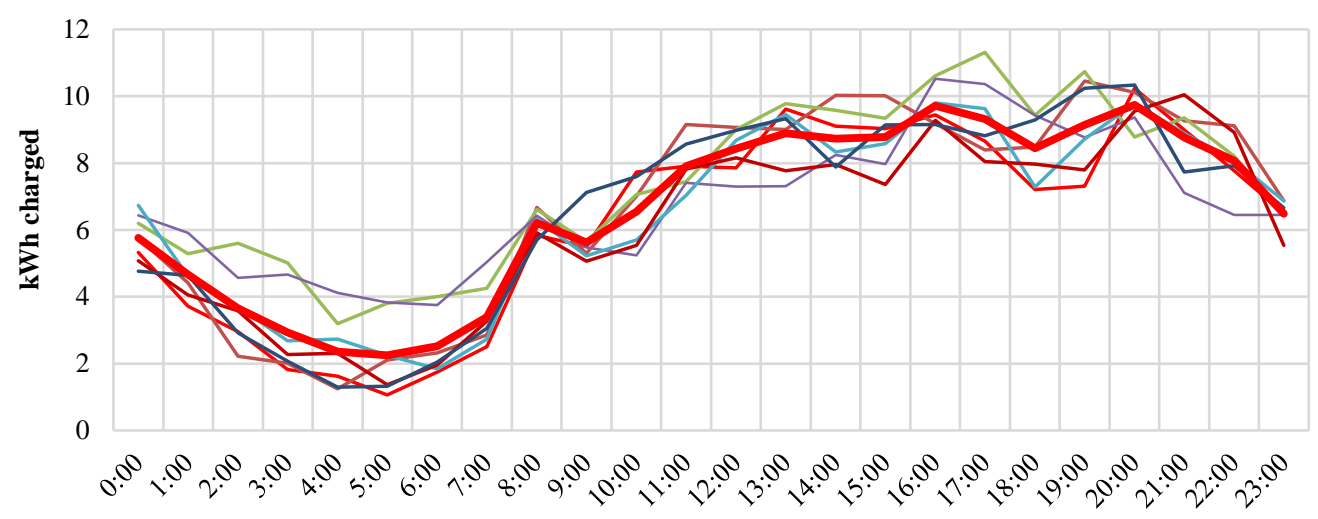

Hour

- Mon $\longrightarrow$ Tue $\longrightarrow$ Wed $\longrightarrow$ Thu $\longrightarrow$ Fri $\longrightarrow$ Sat $\longrightarrow$ Sun $\longrightarrow$ Average

(a)

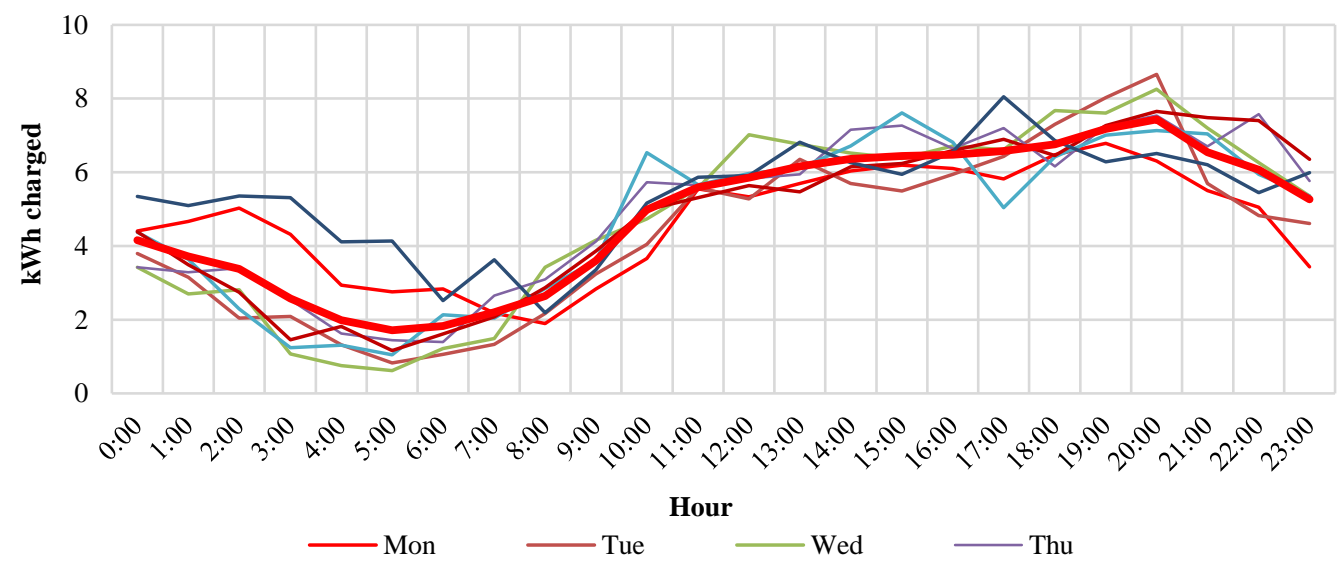

(b)

Fig. 6. Average charged energy during a day: (a) Bauska street; (b) Eizensteina street charging station. 
It is noteworthy, that both stations demonstrate a similar shape of the charging distribution - however there is a well-defined spike around 8:00 in Bauska street charging station which is notably absent in Eizensteina street charging station. Such a difference could be explained by few regular customers charging there every day. As noted previously, the small overall number of EV users might affect the reliability of the data to the general population for the future.

While there are differences between both charging stations at the absolute values of the data, with Bauska charging station being utilized around $20 \%$ more than Eizensteina station; the charging energy distribution during a day was very similar when data was normalized. Table 1 shows the distribution of the charged energy in both charging stations during the day as a percentage of the total amount of energy charged.

TABle 1. AVERage Distribution of CHARged ENERGy DURING THE DAY

\begin{tabular}{lllllllllllll}
\hline Hour & $\mathbf{0 0 : 0 0}$ & $\mathbf{0 1 : 0 0}$ & $\mathbf{0 2 : 0 0}$ & $\mathbf{0 3 : 0 0}$ & $\mathbf{0 4 : 0 0}$ & $\mathbf{0 5 : 0 0}$ & $\mathbf{0 6 : 0 0}$ & $\mathbf{0 7 : 0 0}$ & $\mathbf{0 8 : 0 0}$ & $\mathbf{0 9 : 0 0}$ & $\mathbf{1 0 : 0 0}$ & $\mathbf{1 1 : 0 0}$ \\
\hline Bauskas & $4.8 \%$ & $4.2 \%$ & $3.8 \%$ & $3.1 \%$ & $2.4 \%$ & $2.3 \%$ & $2.7 \%$ & $2.0 \%$ & $2.5 \%$ & $2.7 \%$ & $4.6 \%$ & $5.2 \%$ \\
Eizensteina & $5.0 \%$ & $4.6 \%$ & $4.8 \%$ & $3.5 \%$ & $2.8 \%$ & $1.8 \%$ & $2.0 \%$ & $1.8 \%$ & $1.8 \%$ & $2.8 \%$ & $4.5 \%$ & $4.9 \%$ \\
Average & $4.9 \%$ & $4.4 \%$ & $4.3 \%$ & $3.3 \%$ & $2.6 \%$ & $2.1 \%$ & $2.4 \%$ & $1.9 \%$ & $2.1 \%$ & $2.8 \%$ & $4.6 \%$ & $5.1 \%$ \\
\hline Hour & $\mathbf{1 2 : 0 0}$ & $\mathbf{1 3 : 0 0}$ & $\mathbf{1 4 : 0 0}$ & $\mathbf{1 5 : 0 0}$ & $\mathbf{1 6 : 0 0}$ & $\mathbf{1 7 : 0 0}$ & $\mathbf{1 8 : 0 0}$ & $\mathbf{1 9 : 0 0}$ & $\mathbf{2 0 : 0 0}$ & $\mathbf{2 1 : 0 0}$ & $\mathbf{2 2 : 0 0}$ & $\mathbf{2 3 : 0 0}$ \\
\hline Bauskas & $4.9 \%$ & $4.5 \%$ & $4.4 \%$ & $4.9 \%$ & $5.3 \%$ & $5.0 \%$ & $4.4 \%$ & $5.0 \%$ & $6.1 \%$ & $5.5 \%$ & $5.5 \%$ & $4.4 \%$ \\
Eizensteina & $4.8 \%$ & $4.8 \%$ & $5.1 \%$ & $5.0 \%$ & $4.9 \%$ & $4.2 \%$ & $4.6 \%$ & $5.4 \%$ & $5.7 \%$ & $4.9 \%$ & $5.1 \%$ & $5.3 \%$ \\
Average & $4.8 \%$ & $4.6 \%$ & $4.7 \%$ & $4.9 \%$ & $5.1 \%$ & $4.6 \%$ & $4.5 \%$ & $5.2 \%$ & $5.9 \%$ & $5.2 \%$ & $5.3 \%$ & $4.8 \%$ \\
\hline
\end{tabular}

This pattern also differs significantly from the results reported in research in Ireland, where the charging was distributed more or less uniformly during daytime from 8 AM to 8 PM, then dropping rapidly during night-time [13]. The small number of EV users in Latvia could be responsible for such differences in charger use.

These results can be used for further research on Latvian electric vehicle infrastructure. The data from this research has already been used for modelling the network utilization growth possibilities [23] and opportunities to decrease network operation costs by introducing smart energy and solar charging [24].

The results of this research will also serve as grounds for EU policy implementation in Latvia. The 2014/94/EU Directive determines, that an appropriate number of recharging points accessible to the public are put in place by 31 December 2020 [4]. The European Commission suggested national targets for public charging points - in the EU context, the ideal ratio of PEVs per charging point would lie between 10 and 16 [25] (although that includes opportunity chargers up to $22 \mathrm{~kW}$ ), and data from existing charging network use could be used to justify Latvia's decisions for further charging network development.

\section{Conclusions}

The first year of the operation of national fast-charging network has provided some valuable results for further development of policy of electric vehicles in Latvia. The main conclusions are, that as it was expected, most of the charging events are happening in and around Riga, where most of the electric vehicles are used. However, a third of all charging stations are being used at least once a day, and all charging stations are used at least once a month. The analysis of the charging station users show that the real charging station use is similar to the 
results of the survey two years ago which predicted that $40 \%$ of the users will not be using fast-charging network. $30 \%$ however use the charging network at least half a week and the remaining $30 \%$ have used it at least once.

The research showed gradual increase in the fast-charging network use until introduction of payment in July 2018, which corresponded to sharp drop in charging network utilization rate. At the same time average charging power increased which suggests that people started using the stations only when absolutely necessary.

This lets to conclude that the network is providing a necessary service for the electric vehicles to be used in most of the territory of Latvia, connecting the main cities and covering major roadways.

The extreme concentration of charging events and the unevenness of charger use by users, with $10 \%$ of users being responsible for more than a half of the charging events, might account for the differences noted from similar studies carried out previously in other countries; as it could be affecting the usability of this data to predict the charging network use in the future, as more electric vehicles will appear on the market. Therefore, further analysis will be necessary as more data will become available in the coming months.

\section{ACKNOWLEDGEMENT}

The authors would like to thank Latvian Road Traffic Safety Directorate and in particular Pauls Beinarovičs and Aivis Ozolinš for the support providing data from the Latvian fast-charging network.

\section{REFERENCES}

[1] Ministry of Transport of Republic of Latvia. Electric Mobility Development plan 2014-2016. Riga, 2014.

[2] European Commission. Communication from the Commission to the European Parliament, the Council, the European Economic and Social Committee and the Committee of the Regions. 2020 by 2020: Europe's climate change opportunity COM 2008:1-12.

[3] European Commission. Roadmap to a Single European Transport Area-Towards a competitive and resource efficient transport system, 2011. doi:10.2832/30955

[4] European Union. Directive 2014/94/EU of the European Parliament and of the Council of 22 October 2014 on the deployment of alternative fuels infrastructure. Official Journal of the European Union, 2014.

[5] European Commission. 2030 climate \& energy framework. Climate Strategy \& Targets 2014. doi:10.1007/s13398-014-0173-7.2

[6] UNFCCC Conference of the Parties. Paris Agreement. Geneva: United Nations, 2015.

[7] Intergovernmental Panel on Climate Change. IPCC special report on the impacts of global warming of $1.5^{\circ} \mathrm{C}-$ Summary for policy makers, 2018.

[8] European Environment Agency. Annual European Union greenhouse gas inventory 1990 - 2016 and inventory report 2018, Submission to the UNFCCC Secretariat, 2018.

[9] Cabinet of Ministers of Republic of Latvia. National Energy and Climate Plan of Latvia 2021-2030 (draft). Riga: 2018.

[10] Bariss U., Bazbauers G., Blumberga A., Blumberga D. System Dynamics Modeling of Households' Electricity Consumption and Cost-Income Ratio: a Case Study of Latvia. Environmental and Climate Technologies 2017:20:36-50. doi:10.1515/rtuect-2017-0009

[11] Ministry of Transport of Republic of Latvia. Electric Mobility Development plan 2014-2016. Riga, 2014.

[12] European Commission. Communication from the Commission to the European Parliament, the Council, the European Economic and Social Committee and the Committee of the Regions. 2020 by 2020: Europe's climate change opportunity COM 2008:1-12.

[13] European Commission. Roadmap to a Single European Transport Area-Towards a competitive and resource efficient transport system, 2011. doi:10.2832/30955

[14] European Union. Directive 2014/94/EU of the European Parliament and of the Council of 22 October 2014 on the deployment of alternative fuels infrastructure. Official Journal of the European Union, 2014.

[15] European Commission. 2030 climate \& energy framework. Climate Strategy \& Targets 2014. doi:10.1007/s13398-014-0173-7.2 
[16] UNFCCC Conference of the Parties. Paris Agreement. Geneva: United Nations, 2015.

[17] Intergovernmental Panel on Climate Change. IPCC special report on the impacts of global warming of $1.5{ }^{\circ} \mathrm{C}-$ Summary for policy makers, 2018.

[18] European Environment Agency. Annual European Union greenhouse gas inventory 1990 - 2016 and inventory report 2018, Submission to the UNFCCC Secretariat, 2018.

[19] Cabinet of Ministers of Republic of Latvia. National Energy and Climate Plan of Latvia 2021-2030 (draft). Riga: 2018.

[20] Van den Hoed R., Helmus J.R., de Vries R., Bardok D. Data analysis on the public charge infrastructure in the city of Amsterdam, 2014:1-10.

[21] Green eMotion Project Work packages n.d. [Online]. [Accessed 29.03.2019]. Available: http://www.greenemotionproject.eu/workpackages/index.php

[22] Morrissey P., Weldon P., O’Mahony M. Future standard and fast charging infrastructure planning: An analysis of electric vehicle charging behaviour. Energy Policy 2016:89:257-70. doi:10.1016/j.enpol.2015.12.001

[23] Raslavičius L., Azzopardi B., Keršys A., Starevičius M., Bazaras Ž., Makaras R. Electric vehicles challenges and opportunities: Lithuanian review. Renewable and Sustainable Energy Reviews 2015:42:786-800. doi:10.1016/j.rser.2014.10.076

[24] Joller L., Varblane U. Learning from an electromobility living lab: Experiences from the Estonian ELMO programme. Case Studies on Transport Policy 2016:4(2):57-67. doi:10.1016/j.cstp.2015.11.001

[25] Putnieks U., Gailis M., Kancevica L. Analysis on electric vehicle charging infrastructure in Latvia. Engineering for Rural Development, 11th International Scientific Conference, Latvia University of Agriculture, 2012, p. 400-405.

[26] Berjoza D., Jurgena I. Analysis of distribution of electric vehicle charging stations in the Baltic. Engineering for Rural Development, 14th International Scientific Conference, Latvia University of Agriculture, 2015, p. 258 -264.

[27] Rubenis A., Berjoza D., Grīslis A., Francis I. Analysis of the development of the Latvian national electric vehicle charging network (in Latvian). Riga: 2016.

[28] The Ministry of Environmental Protection and Regional Development of the Republic of Latvia. "Reduction of greenhouse gas emissions in the transport sector - aid for the introduction of electric vehicles and their charging infrastructure", 2014. [Accessed 20.05.2016]. Available: http://www.varam.gov.lv/lat/darbibas_veidi/KPFI/projekti/?doc=17817

[29] IEEE Std 2030.1.1-2015: IEEE Standard Technical Specifications of a DC Quick Charger for Use with Electric Vehicles. IEEE 2016; 2016.

[30] IEC. IEC Standard IEC 62196 2011. [Accessed 28.03.2019]. Available: https://www.iecee.org/dyn/www/f?p=106:49:0::::FSP_STD_ID:20348

[31] Cabinet of Ministers of Republic of Latvia. Grozijums Ministru kabineta 2013. gada 24. septembra noteikumos Nr. 1000 "Valsts akciju sabiedrības "Ceḷu satiksmes drošības direkcija" publisko maksas pakalpojumu cenrādis". Riga: Cabinet of Ministers of Republic of Latvia: 2018.

[32] Klemka J., Rubenis A., Zvirbule A. Development of model for increasing electric vehicle charging capacity with limited available grid power. Engineering for Rural Development, Jelgava: 2019.

[33] Klemka J., Rubenis A., Adrian L. The opportunities for electric vehicle fast charging networks in Northern regions using smart charging. Engineering for Rural Development, Jelgava: 2019.

[34] Spöttle M., Jörling K., Schimmel M., Staats M., Grizzel L., Jerram L. et al. Charging infrastructure for electric road vehicles. European Parliament Policy Department for Structural and Cohesion Policies, 2018. doi:10.2861/013597. 